\title{
FDI and the labour market: A review of the evidence and policy implications.
}

\author{
Nigel Driffield ${ }^{\mathrm{a}}$ and Karl Taylor ${ }^{\mathrm{b}}$
}

${ }^{\mathrm{a} B i r m i n g h a m ~ B u s i n e s s ~ S c h o o l, ~ U n i v e r s i t y ~ o f ~ B i r m i n g h a m, ~}$

Edgbaston, Birmingham. B15 2TT

${ }^{\mathrm{b}}$ Economics section, Cardiff Business School, Cardiff University, Aberconway Building, Colum Drive, Cardiff. CF10 3EU

Paper prepared for the special edition of Oxford Review of Economic Policy on Globalisation and Labour Markets

Autumn 2000. 


\section{Abstract}

This paper presents a series of results concerning the labour market impact of inward FDI in the UK. The paper demonstrates that one of the crucial impacts of FDI is to increase earnings dispersion and the use of relatively more skilled labour in the domestic firms. This result is found to be a combination of two effects. Firstly, the entry by an MNE increases the demand for skilled workers in an industry or region, thus increasing wage dispersion. Secondly, technology spillovers occur from foreign to domestic firms. As a result of these spillovers, relative demand for skilled workers increases in the domestic firms, further contributing to aggregate wage dispersion and skill upgrading. The paper also considers how FDI impacts upon skill shares by productivity differentials between foreign and domestic firms. Finally, the policy implications of this are then discussed, from the perspective of regional development, and the likely effectiveness of attracting FDI to reduce structural unemployment. 


\section{Introduction}

In recent years both academics and policy makers have expressed concern that increasing globalisation, both in the form of FDI and international trade, is causing dramatic changes in labour demand in the developed world. Specifically, it has been suggested that demand for unskilled workers in the US and Western Europe has been, and will continue to decline dramatically, as the employers of unskilled workers face significant competition from the NICs and other parts of the developing world.

In addition, concern has also been expressed that the actions of foreign owned firms in western economies have exacerbated this, generating greater wage differentials for skilled workers than have hitherto been observed. Such empirical work as has been done in this area suggests that the increased demand for skilled workers is a combination of two effects. Firstly, that the entry of MNEs, in possession of technological advantage over domestic firms, yields productivity differences between national and foreign firms influencing wages directly. There is growing evidence for this in the UK - Driffield (1996) finds that foreign firms will pay wages above the industry average of around $7 \%$, partly due to productivity differences, Conyon et al. (1999) find a wage differential of $3.4 \%$ wholly attributable to productivity, and Girma et al. (1999) find wage and productivity differentials of 5\%. Within the international business literature, this is generally characterised as the technological or “ownership” advantage that MNEs possess over domestic firms. Following on from this, it is then assumed, and indeed confirmed by empirical evidence, that foreign owned firms have different factor demands for labour in comparison to domestically owned firms - even within the same industry, Driffield (1999). 
Figure $1 \underline{\text { Wage shares and foreign affiliate employment: UK manufacturing } 1983 \text { to } 1992^{1}}$

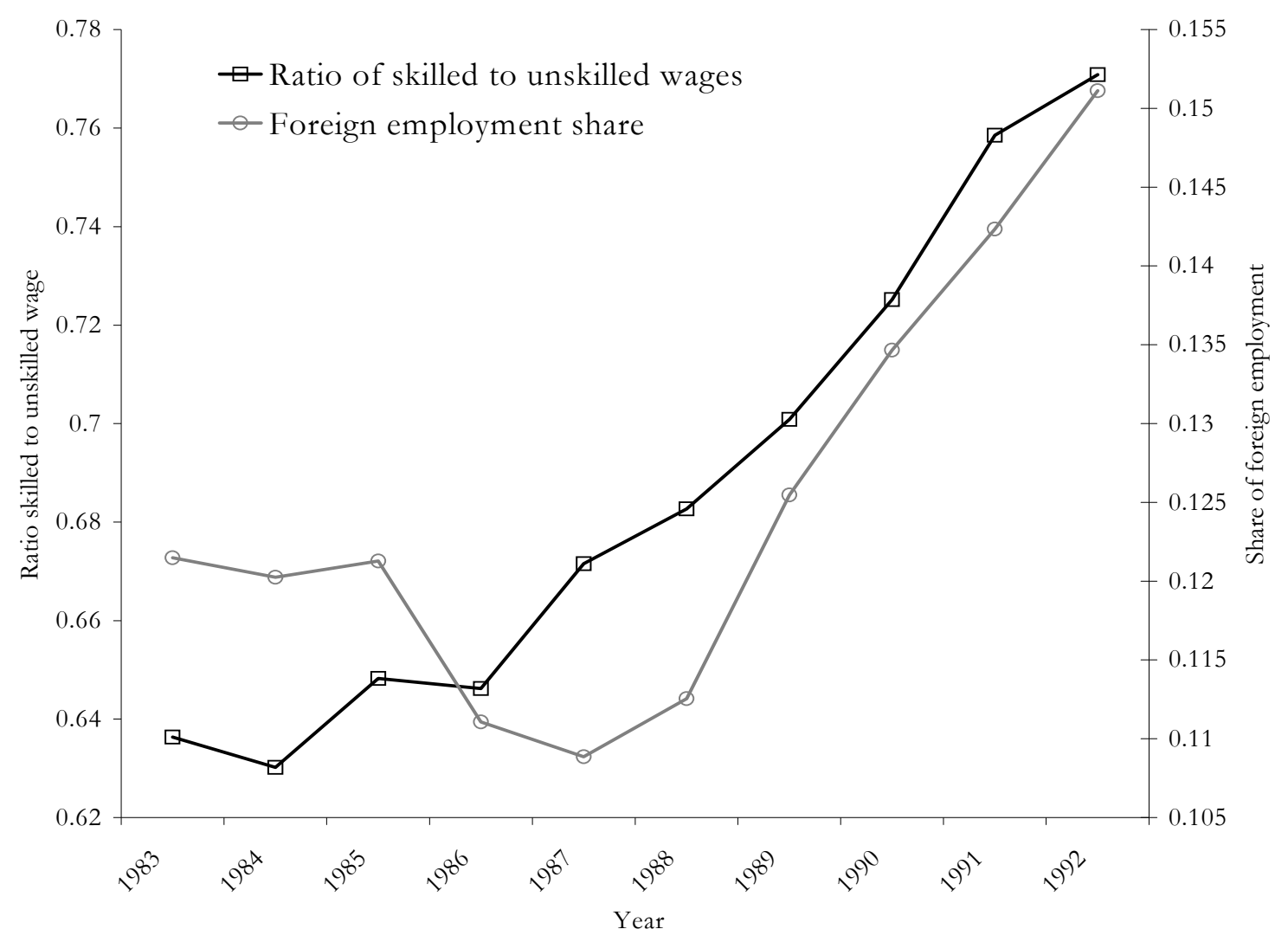

Notes: The ratio of skilled to unskilled wages is measured as the average annual wages of non-operatives (skilled) divided by the average annual wages of operatives (unskilled) in UK manufacturing. Our measure of unskilled workers (operatives) includes all manual wage earners i.e. operatives in power stations, engaged in outside work of erecting, fitting etc., inspectors, maintenance workers and cleaners. Staff engaged in transport (including roundsmen) and employed in warehouses, stores, shops and canteens are also included in the definition.The foreign employment share is defined by the proportion of total UK manufacturing employment accounted for by foreign owned multinationals.

Source: Census of Production, ONS.

\footnotetext{
${ }^{1}$ As with much previous research our data only allow us to distinguish between two groups of labour one interpreted as skilled (non-operatives) and the other unskilled (operatives). The disadvantage is that one may lose much information about the subtleties of the wage structure from this degree of aggregation - Autor and Katz (1999), Taylor (1999). However, Berman et al. (1994) and Machin and Van Reenen (1998) find that such aggregations do a reasonable job of matching a high/low educational breakdown in manufacturing.
} 
The second effect is essentially a spillover effect. This concerns the extent to which the new (to the host country) technology that accompanies the FDI is assimilated by the domestic sector. If this occurs, it will increase the productivity of skilled workers still further in the domestic sector, increasing demand for skilled workers at the expense of unskilled workers. Figure 1, above, shows that at a time of increasing shares of foreign employment that the wage gap between skilled and unskilled workers has also risen. This paper discusses the likely impacts of these indirect labour market effects, and the challenges that they set policy makers. In the UK for example, there are many regional development agencies (RDAs), each with a significant degree of autonomy. These agencies are effectively attempting to address the problem of structural unemployment in their region, by attracting inward investment. However, the impact of this on skills, income distribution and wages are commonly seen as secondary to the number of people who will be directly employed by the MNE.

It is possible that foreign firms don't actually employ more skilled workers, rather in industries of high FDI there are already more skilled workers. However, we present evidence that there are clear differences in employment patterns between domestic and foreign firms. Comparing differences in employment patterns between foreign and domestically owned firms, Figure 2 below, shows the ratio of skilled to unskilled employment over time for the foreign and domestic sector. This clearly shows that foreign firms over the period, were significantly more skill intensive than domestic firms. For example, in 1983 the ratio between skilled and unskilled wages in the domestic and foreign sector was $48 \%$ and $58 \%$ respectively, by 1992 it had risen to 53\% and 66\%. This suggests, that part of the "spillover" process is likely to involve the domestic sector becoming more skill intensive. There is clear evidence of the domestic sector becoming more skill intensive, but less evidence that they actually closed the gap on the foreign firms over the period, in fact if anything the gap 
increased. It is also interesting that, while the foreign wage differential, for manual workers was of the region of $7 \%$, this also holds for non-manual workers, and as such the skill premium is equally evident across the two sectors.

Figure 2 Ratio of skilled to unskilled employment in the foreign and domestic sector: UK manufacturing 1983 to 1992

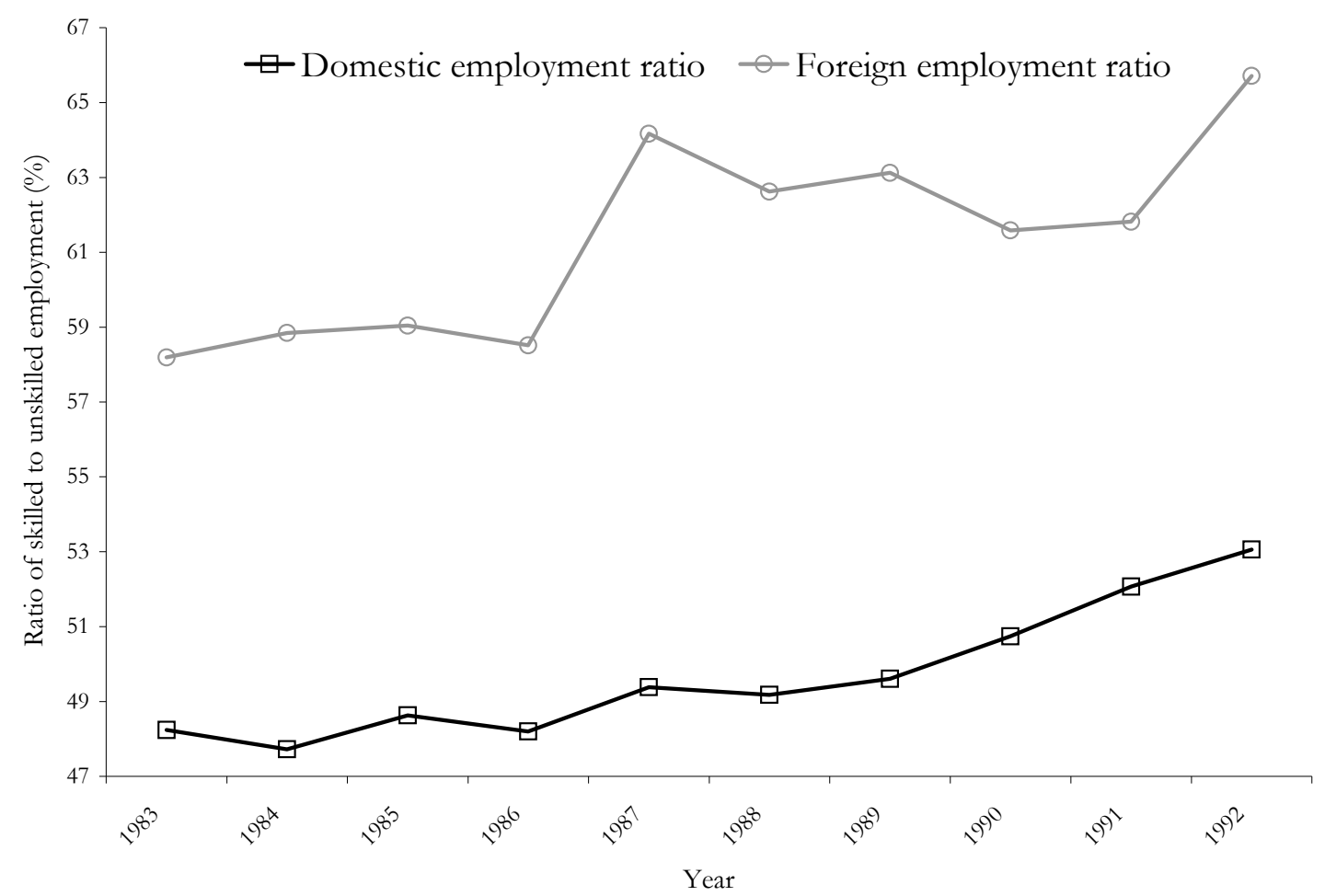

Notes: The ratio of skilled to unskilled employment is measured as the employment of nonoperatives (skilled) divided by the employment of operatives (unskilled) in UK manufacturing, for foreign and domestic sectors. For further details see notes to Figure 1.

Source: Census of Production, ONS.

\section{FDI and Industrial Relations}

From the late 1980's to the mid 1990's, there was a debate in the Human Resource Management (HRM) and Industrial Relations (IR) literature concerning the "Japanisation" 
of UK industry. This was essentially concerned with the increased influence that Japanese management practices were having on UK firms, see for example Oliver and Wilkinson (1993). As Oliver and Wilkinson (1993) note, there was up to that time, "a sense of urgency, almost of evangelism” within many Western firms, to copy what at the time was seen as best practice in the organisation of production. This belief was based on the apparent Japanese miracle of the 1970's and 1980's, with studies finding huge productivity differences between Japan and the West ${ }^{2}$.

However, Morris and Wilkinson (1995) question the extent to which the management techniques that are apparent in Japan, have actually been applied in Western economies. They claim, citing other authors such as Delbridge et al. (1992), that Japanisation has been little more than an increase in intensity in the workplace, through the imposition of tighter management controls through surveillance and discipline. Morris et al. (1993) argue that Japanese firms, with their insistence on single union deals, have experienced few industrial relations problems in Wales, and it is likely that some of the observed labour productivity differentials can be attributed to this. However, the scale of Japanese investment into the UK is still small, compared with the stock of US or EU foreign capital here (Morris et al., 1993), so it would be easy to over-emphasise the importance of this issue in more general terms.

\section{Inward investment policy in the UK and the labour market}

It is on the basis of the link between inward investment and regional development, that it may be argued that attracting FDI has been the chief industrial policy of UK authorities over the past 20 years, see for example Eltis (1996), and Eltis and Fraser (1992). However, as

\footnotetext{
${ }^{2}$ This literature is similar to a recent line of economic thought that has been advanced, where organisational change over time can help to explain rising earnings dispersion or skill shares by requiring workers to be able to shift between numerous tasks as organisations move from "Tayloristic" to "Holistic" structures (Lindbeck and Snower,1996)
} 
Morgan (1997) notes, such policies have been designed to address the symptoms of regional disparities, such as unemployment, rather than the underlying causes, such as low levels of technological development. An important question therefore is the extent to which inward investment will contribute to alleviating the underlying causes of regional underdevelopment, as well as simply generating employment. Of particular importance, given the issues discussed above, is the extent to which FDI increases wage inequality rather than acting to reduce disparities, which is the avowed aim of regional policy.

Many regions of the UK, in common with most of Europe, have Development Agencies, who have come to see themselves as the marketing function for the region, in terms of attracting internationally mobile investments. Nijkamp and Blaas (1995) examine

Figure $3 \underline{\text { Share of regional manufacturing employment accounted for by foreign firms }}$

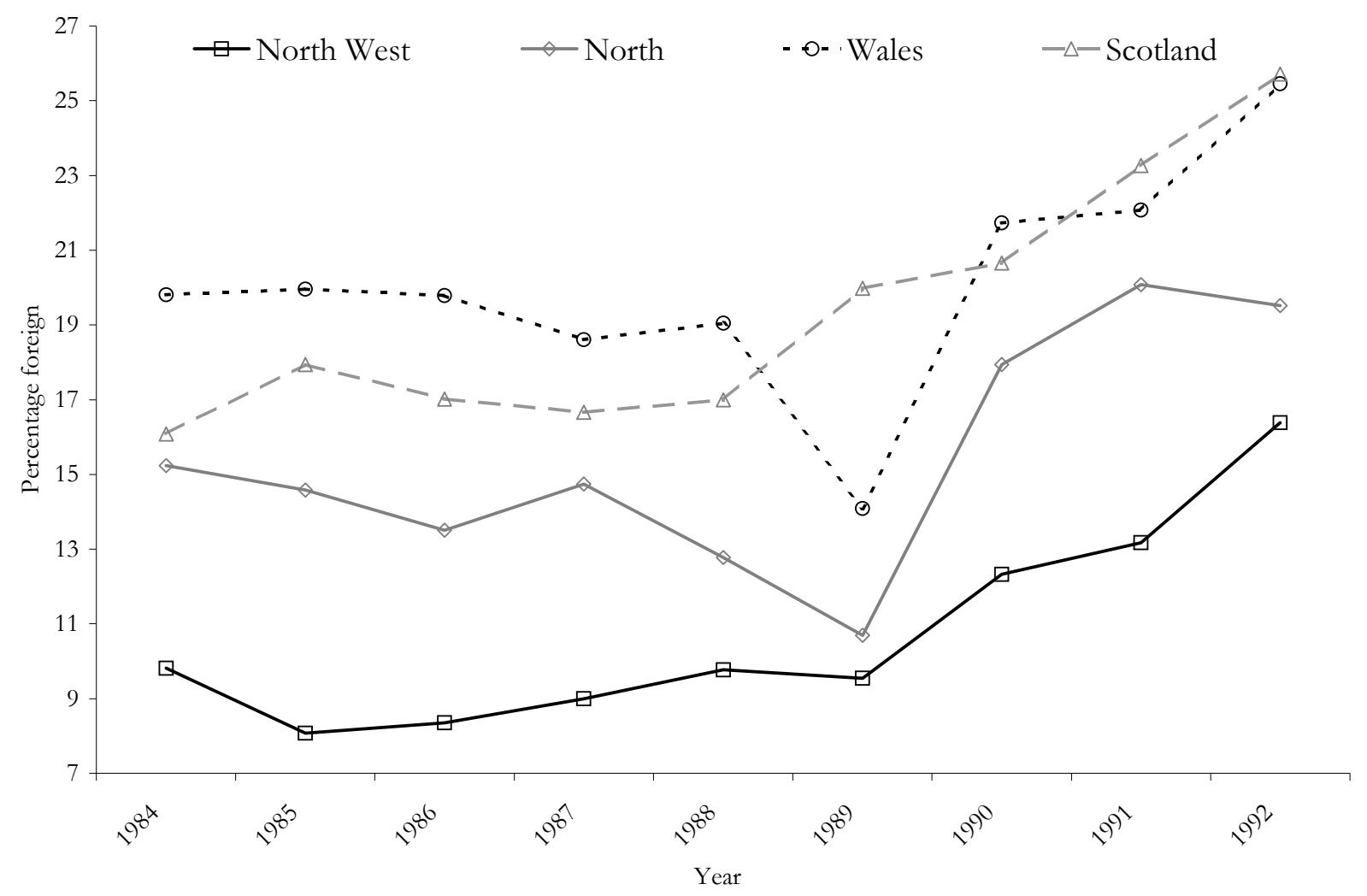


how the European Regional Development Fund (ERDF) has influenced private investment rates across European Regions, and Hill and Munday (1994) provide similar results in terms of domestic regional inward investment incentives for the UK. Indeed, Wren and Taylor (1999) go one stage further, demonstrating that investment incentives have had the effect of changing the regional distribution of economic activity across the UK in general. As such, it is clear that investment incentives have had the effect of encouraging firms to locate away from regions that demonstrate a more obvious location advantage. Consequently, spillovers from inward investment are perhaps lower than may be expected, for further discussion on this see Amin (1999) and Lovering (1999). It is clear therefore, that several regions of the UK, in particular those perhaps hardest hit by the structural changes in UK manufacturing, have significantly increased their reliance on foreign investment in terms of employment and output, as shown in Figure 3 above. While this in general is seen as a sign of success, both by and for the respective development agencies, the issue of the long term benefits of such a policy, and its contribution to the reduction in structural unemployment is still open to question.

\section{Labour market impacts of FDI}

Recent research highlights several effects that FDI can have on wage rates, productivity and wage differentials. Firstly, foreign firms entering an industry will pay wages above the industry average due to productivity differences (Driffield, 1996) - the actual impact upon the skill premium is ambiguous here and depends on how the skilled and unskilled are distributed within industries. The second impact of increasing inward FDI will be through a learning process (Barrell and Pain, 1997; Figini and Görg, 1999) whereby technological advantages are transferred to domestic producers (Blomstrom, 1989; Haddad and Harrison, 1993). To the extent that technology favours skilled workers the effect of FDI 
upon inequality should be to have a positive impact upon skilled wages although having a diminishing impact as all workers move to become skilled over time ${ }^{3}$.

While it is not the purpose of this paper to discuss at length the theoretical explanations of FDI, it is necessary to briefly consider the central explanations of FDI. These can essentially be divided into two categories, those based on the concept of ownership advantages, following Dunning (1979), and a separate strand where FDI is explained in terms of rivalrous behaviour by oligopolists, seeking to enhance their market power. For example, Horstman and Markusen (1996), or Motta (1996), following Graham (1978), suggest that FDI can be explained as rivalrous behaviour between oligopolists, as well as in terms of ownership advantages or location advantages. The distinction here is important from a policy perspective. It seems clear, from work such as Eltis and Fraser (1992), or Morgan (1997), that inward investment policy has been firmly based on the assumption that ownership advantages will, as a result of FDI, be transferred to the domestic sector. If however, one is to expect an externality following inward investment based on rivalry, then this may be due to increased competition, rather than technology transfer. For the purpose of this paper, it is sufficient merely to note these competing (although possibly not mutually exclusive) explanations of FDI, and the resulting inferences concerning the likely impact on domestic productivity following the investment. However, it should also be noted, that there is compelling evidence, that whatever the motives for inward investment into the UK, the foreign owned sector possesses a significant productivity advantage over the domestic sector, see for example Davies and Lyons (1991), or Driffield (2000).

There has been a good deal of work carried out on measuring the benefits to the UK of inward investment. The most obvious are the gains in terms of direct employment creation

\footnotetext{
${ }^{3}$ This reasoning is similar to the impact over time of general purpose technologies upon wage differentials (Aghion and Howitt, 1998).
} 
and regional development. The impact of inward investment on employment generation and regional development is assessed in Young et al. $(1988,1994)$ and Neven and Siotis (1993). Equally important are the considerations highlighted by Dunning (1988a). Inward investment will increase allocative efficiency in the economy, as resources are reallocated to more efficient producers. Inward investment improves the balance of trade for the host country, both in the short term through the inflow of capital, and in the longer term through exports, Dunning (1988b). Finally, there is therefore a relatively recent literature based on the extent to which these technological advantages are transferred to domestic producers, see for example Blomstrom (1989) and Haddad and Harrison (1993).

The importance of FDI for host economies is highlighted recently in Barrell and Pain (1999). FDI is clearly seen to act much faster than international trade, as a mechanism for international technology transfer. This distinction is highlighted by Hood et al. (1999) who show that inward investors in the UK have stimulated significant local linkages, which in turn are expected to encourage skill upgrading and productivity growth in domestic suppliers. Further, Ruane and Görg (1999) show that, for Eire, FDI has contributed, not only to aggregate employment, but that particular gains have been made in high technology sectors, where one may expect the potential for technology transfer to be important. Belitz and Beise (1999) also show that there is a distinct trend for R\&D to become internationalised, although this will, as ever, be constrained by the significant scale economies available in R\&D. However, Belitz and Beise also suggest that this occurs through acquisition rather than Greenfield investment, and may therefore be suggestive of technology sourcing as well as internationalisation of R\&D. The link between R\&D and FDI has been understood for some time, see for example Driffield and Munday (2000), although the suggestion is that R\&D facilitates foreign entry, via the creation of firm-specific assets, rather than as a mechanism 
for MNEs to acquire local technology. Again, in such circumstances, one would expect technological externalities to accrue to the domestic sector.

To identify the link between inward investment and within-industry shifts in demand towards higher skilled labour, we exploit variations in FDI across manufacturing industries. The empirical framework used to assess the impact of FDI upon wage shares and skilled employment shares is based upon a flexible translog cost function following the approach of Berman et al. (1994), Machin and Van Reenen (1998). To consider the role of FDI we control for technology and the impact of trade, since these are the two main explanations for the relative demand shift in favour of skilled labour (Gottschalk and Smeeding, 1997). Including proxies for technology and trade has been advocated by Feenstra and Hanson (1995, 1996), Autor, Katz and Krueger (1998), and Blonigen and Slaughter (1999). These are justified by the inclusion of potential demand shifters, such as technology and trade, by arguing that merely including the factors derived from theory ${ }^{4}$ will not capture other influences which could effect a firms demand function. Akin to this argument we also justify the inclusion of FDI in the empirical specifications. Our measure of technology is the stock of research and development expenditure as a proportion of value added, and globalisation is defined by import expenditure as a proportion of value added. Data on R\&D intensity is commonly used in the literature as a proxy for technology (Machin and Van Reenen, 1998; Berman and Machin, 2000) and import intensity has also been extensively used to proxy the role of international trade upon the labour market (Berman et al., 1994; Anderton and Brenton, 1999).

\footnotetext{
${ }^{4}$ Using a translog cost function, after cost minimisation and assuming homoeneity of degree one in prices yields a two factor cost function - in our case skilled and unskilled labour. Essentially capital, output and relative wages are the factors which influence a two factor cost function.
} 
Table 1 below summarises some of our recent work, showing how technology, trade and FDI have impacted upon the skilled wage share (columns 1 and 2) and skilled employment shares (column 3) in the domestic sector of UK manufacturing. All the estimation is by two way random effects to control for unobservable fixed effects and time effects $^{5}$ (note we obtain very similar results when estimation is carried out in first differences by GMM).

Initially we wanted to see whether FDI could be considered to have a learning effect upon wage differentials (following Barrell and Pain, 1997; Figni and Görg, 1999), where technological advantages are transferred from foreign to domestic producers in the form of spillovers. In the first and second columns of Table 1 below we consider how FDI has influenced the share of skilled wages, using two different definitions of FDI. In the first column FDI is defined by the share of total UK manufacturing employment accounted for by foreign multinationals, following Blonigen and Slaughter, 1999. In the second column we define the impact of FDI by the share of net capital expenditure by foreign firms in the UK to see how robust the results are. Technological diffusion through FDI is likely to involve time lags and so the FDI variable is lagged. Under both definitions, the results show that FDI takes two years to have its full effects upon the labour market which can be interpreted as a learning effect (Barrell and Pain, 1997; Figni and Görg, 1999). Essentially, increasing FDI activity over time leads to technology spillovers into the domestic sector which are biased

\footnotetext{
${ }^{5}$ There are advantages to estimating in levels, which having the stock of R\&D intensity rather than its flow enables us to do so. Much of the literature has sought to explain fluctuations in wage shares by analysing data that has been first differenced or detrended. In the case of panel data an approach often adopted to control for unobserved time invariant industry fixed effects is to first difference data. However, this type of analysis removes the trend component, where clearly the long term persistent movements of the trend in relative wages is of importance. By first differencing data researchers are only analysing year to year growth rates (Borjas and Ramey, 1994). Furthermore, estimating in levels allows an increase in a variable to influence the dependent variable in subsequent periods, this is reasonable if the effects are felt gradually over time - which is quite likely in the case of technology, trade and especially FDI spillovers.
} 
towards skilled labour and so the relative demand for skills increases yielding rising wage dispersion. These results are consistent with findings for Ireland Figini and Görg (1999) ${ }^{6}$.

Table 1 Impact of FDI upon wage shares and relative employment

(1)

Wage share
(2)

Wage share

$0.0041(1.2)$

$0.0055(3.0)$

$0.0357(2.2)$

FDI $(t)$

$0.0008 \quad(1.8)$

$0.0008 \quad(1.7)$

$0.0169 \quad(1.9)$

FDI(t-1)

$$
0.0011 \quad(2.6)
$$

$0.0487 \quad(2.8)$
High productivity

$0.443 \quad(3.7)$

Medium productivity

$0.481 \quad(2.5)$

Low productivity
(3)

Employment ratio

\begin{tabular}{cccc}
\hline Observations & 808 & 808 & 909 \\
$\bar{R}^{2}$ & 0.253 & 0.355 & 0.243 \\
\hline
\end{tabular}

Notes: In columns $1 \& 2$ the dependent variable is the skilled wage share defined as the wages of the skilled (non-operatives) as a proportion of the total wage bill (as in common in the literature). In the $3^{\text {rd }}$ column the employment ratio is skilled (non-operatives) employment divided by unskilled (operatives) employment. All estimation is by two way random effects, chosen in preference to fixed effects estimation by a Hausman test. Regressions were weighted by industry size. R\&D data (from Business Monitors MO14 \& ONS Bulletins) are converted to the stock of $R \& D$ capital by summing over the previous seven years expenditure and then discounting by 10\% per annum. Import data are from Business Monitors MQ10. Both the R\&D stock and import expenditure are weighted by sales to obtain their intensity.

Source: Column 1 Taylor and Driffield (2000) Table 3, Column 2 Driffield and Taylor (2000) Table 3. Data is at the 3 digit industry level SIC 2-4 (1980) from 1983 to 1992. Census of Production, ONS.

\footnotetext{
${ }^{6}$ The only other work which has considered the impact of FDI upon wage dispersion in the domestic labour market is Blonigen and Slaughter (1999) for the USA who find that FDI has an insignificant effect upon wage dispersion. Neither Blonigen and Slaughter (1999) nor Figini and Görg (1999) control for other possible demand shifters apparent in the literature namely trade and technology.
} 
Throughout Table 1 technology outweighs the impact of trade upon both skilled wage shares and relative employment (also true if FDI is excluded) and is what we would expect given the evidence to date (Machin and Van Reenen, 1998; Berman and Machin, 2000).

In a review of FDI spillover effects Blomström et al., (1999) argue that the impact of foreign firm activity differs across domestic industries depending upon the productivity of foreign firms relative to the productivity of domestic firms. Driffield and Taylor (2000) attempt to isolate the spillover effects upon skilled employment shares from FDI by relative productivity differentials between foreign and domestic labour markets, to test whether there is any empirical evidence for the Blomström et al., (1999) assertion. Driffield and Taylor (2000) define three relative productivity groups - high, medium and low, where the impact of FDI upon the labour market is expected to be greatest when the productivity of foreign to domestic firms is similar. We define relative productivity as

$$
A=(\text { Foreign labour productivity } \div \text { Domestic labour productivity })
$$

and A* is the optimal ratio which is essentially an empirical matter. Davies and Lyons (1991) estimated the average productivity advantage that foreign MNEs possess over the domestic sector to be $20 \%$. Clearly, one would not expect significant spillovers where there is no foreign productivity gap, so the cut off points employed are 1, and 1.2 - that is we would expect $A^{*}$ to be approximately equal to 1.2 . Relative productivity is ranked and split into three groups (high, medium and low) and then interacted with FDI. The results show, see the third column of Table 1, that even after controlling for the factors most prevalent in literature capable of explaining relative employment shifts - namely technological change and globalisation, that $\mathrm{FDI}^{7}$ has a role to play in influencing employment trends. In particular, we

\footnotetext{
${ }^{7}$ To consider the impact of FDI upon domestic employment shares multinational activity is defined by the share of net capital expenditure by foreign firms, as in column two. We don't use the employment definition of FDI (column 1) due to possible endogeneity problems. However, the results are robust to defining FDI by the share of capital investment made by foreign owned firms and the share of industry sales from foreign owned firms.
} 
also find evidence that the impact of FDI is greater when the productivity of foreign and domestic firms is similar. The coefficients on FDI from column 3 Table 1 suggest that the impact of FDI across relative productivity sectors is skewed towards the higher end, in other words the actual spillover effects are likely to be as depicted in Figure 4 below. We also

Figure 4 Spillover effects from FDI by relative productivity: A skewed relationship

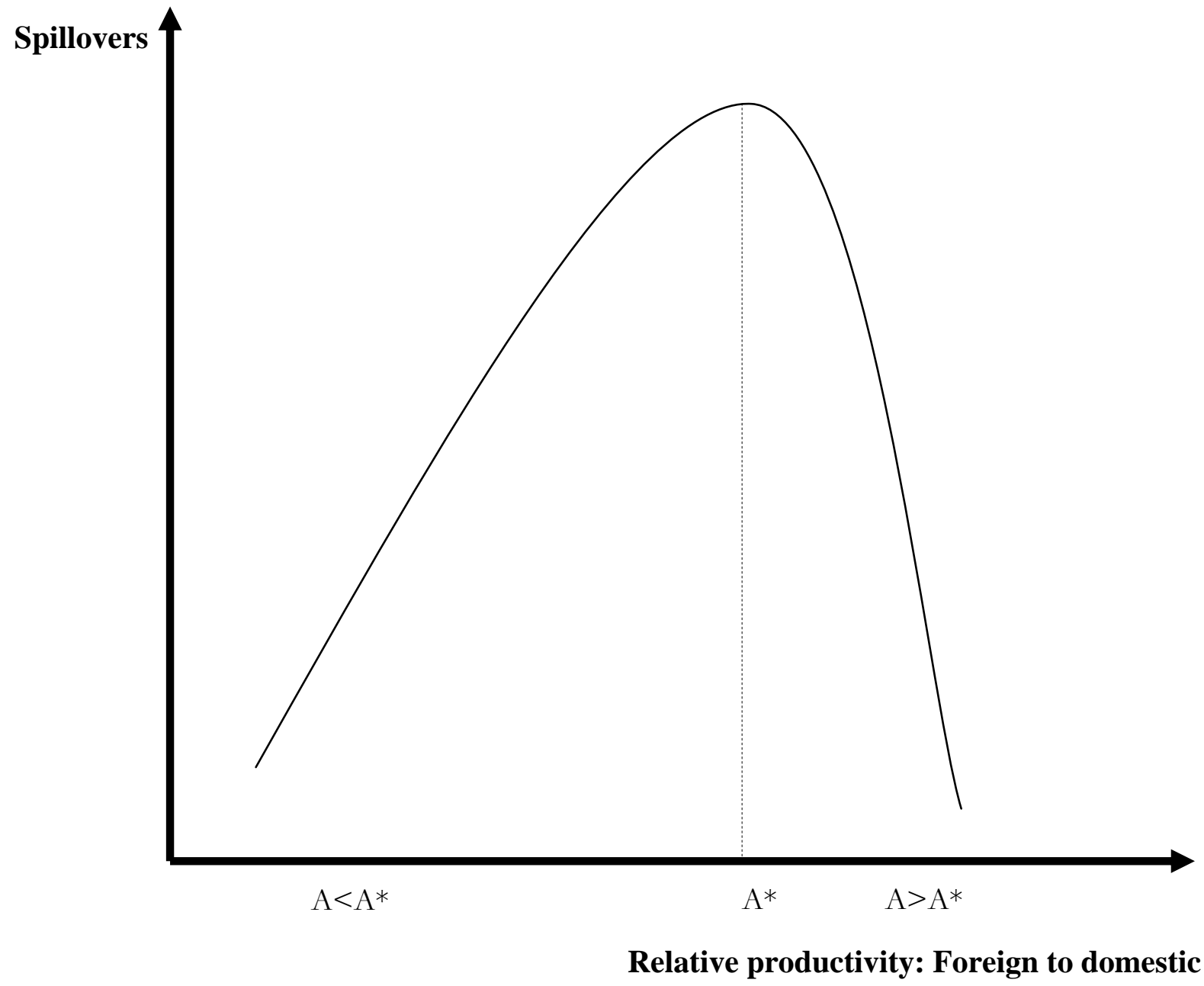

impose the restriction that the impact is the same across sectors of high, medium and low productivity differentials, however this is rejected at the $1 \%$ level (p-value of 0.04 ) and so supports the notion given in Figure 4.

To give some idea of the extent to which multinational activity has influenced the demand for relatively more skilled labour, we use the coefficients in Table 1 to assess what 
proportion of wage dispersion and changing employment shares FDI can account for. Table 2 shows the results of this analysis, the first and second columns give the cumulative impact of FDI (under different definitions) upon wage dispersion and the final column the impact upon skill shares. Clearly, FDI spillovers can explain a larger proportion of the change in employment shares, on average $8.2 \%$, than the change in wage dispersion. This is also true based upon different definitions of FDI, see Taylor and Driffield (2000) and Driffield and Taylor (2000).

Table 2 Comparing the impact of FDI upon the wage share and relative employment

(1) (2) (3)

Wage share Wage share Employment

ratio

Cumulative FDI effects $\quad 0.06 \% \quad 2.2 \%$

FDI $\times$ high relative productivity $A>A^{*}$

$8.79 \%$

FDI $\times$ medium relative productivity $A \approx A^{*}$

$9.54 \%$

FDI $\times$ Low relative productivity $A<A^{*}$

$6.17 \%$

Notes: From the elasticities associated with FDI (given in Table 1 above), it is possible to derive the changes in the domestic wage dispersion and skill shares that occurred over the period 1983 to 1992 as a result of FDI spillovers. Defining FDI by relative foreign employment share and the foreign capital share changes in wage dispersion over the period 1983 to 1992 can be given by $\partial\left(W_{s} / W_{u}\right)=(\delta \times \partial F D I) \times\left(W_{s} / W_{u} \div F D I\right)$. Similarly, the change in the domestic employment share due to inward investment is defined as $\partial\left(N_{s} / N_{u}\right)=(\pi \times \partial F D I) \times\left(N_{s} / N_{u} \div F D I\right)$, where FDI is defined by the foreign capital share. Domestic and foreign sectors are referred to as $D$ and $F$ and the coefficients $\delta, \pi$ are the elasticities, from Table 1 above, associated with the impact of FDI upon wage dispersion (the cumulative effect) and skill shares.

Source: Taylor and Driffield (2000) Columns 1 and 2, Table 5, and Driffield and Taylor (2000) Column 3, Table 4. Data as in Table 1, above. 


\section{FDI and labour productivity}

Likely impacts of FDI on wages or employment, should not be seen in isolation from the likely effects on domestic productivity. The significance of spillovers from multinational enterprise was demonstrated by Barrell and Pain (1997), who estimated that around 30\% of the productivity growth in UK manufacturing between 1985 and 1995 could be associated to the impact of inward investment. The most optimistic results concerning regional benefits are reported by Young et al. (1988) and Neven and Siotis (1993). They contend that the multipliers associated with inward investment are extremely high, possibly due to the regions on which research is concentrated. Such results however, are in general based on studies which examine productivity growth in the aggregate, that is, including the simple 'batting average effect' that is likely to result from new entry, be it foreign or domestic. Nevertheless, studies have also shown that large inward investing groups can attract and promote the development of supplier clusters (Morris et al. 1993), and also play a role in the development of a region's social and physical infrastructure (Peck 1996; Morgan 1997). Equally, as Driffield and Munday (2000) show, inward investment can act to improve domestic performance, and improve revealed comparative advantage.

However, the relationship between FDI and productivity gains is far from clear-cut. De Mello (1999) for example reports a negative relationship between domestic productivity growth and inward investment. This, he ascribes to the 'capital deepening' problem, that total factor productivity growth is reduced, as FDI fosters producer capital accumulation. Aitken and Harrison (1999) however express this phenomenon somewhat differently. They suggest that FDI has two simultaneous effects on productivity growth. The first, is a positive effect associated with spillovers and technology transfer. The second is a 'competitive' effect, which to borrow from Aitken and Harrison (1999), suggests that the increased output by the foreign sector has the effect of reducing the scale of operation of the domestic competitors, 
thus (perhaps) preventing firms from benefiting from potential scale economies and, thus reducing productivity.

This suggests therefore, that there are at least two distinct effects likely to lead to the perceived employment gain from FDI to be smaller than may be anticipated. Firstly, there is the indirect wage effect, identified by Driffield (1999) and others, that inward investment causes wages to rise in the domestic sector, and therefore employment falls. Secondly, there is what can be thought of as the "competitive” or product market effect, identified by Aitken and Harrison (1999), that sales by domestic firms are likely to decline, as a result of increased foreign penetration, and therefore, one expects, reduce employment.

However, evidence is also emerging that the actions of MNEs have a further effect on domestic firms. Figini and Görg (1999), Blonigen and Slaughter (1999) and Taylor and Driffield (2000) all examine the impact on wage differentials of an increase in inward investment. Whilst Blonigen and Slaughter (1999) for the USA do not find any impact the other two papers find that inward FDI has the effect of increasing the industry level wage differential between skilled and unskilled workers. The inference here is that inward FDI has two simultaneous effects. The observed significant effect on aggregate wage differentials is assumed to be a combination of increased demand for skilled labour, following foreign entry, and technology spillovers increasing the productivity of skilled workers in the domestic sector. Taking these in turn, the aggregate effect may be indicative of FDI improving the skills base of the economy, if significant training occurs as a result of this increased demand for skilled workers. However, there is evidence that rather than MNEs engaging in the training of skilled workers, most skilled workers are hired from other firms, while many technical posts are filled initially at least by ex-patriots. While such an effect may still be suggestive of an improvement of the technological base of the economy as outlined by 
Barrell and Pain (1997) and Hubert and Pain (1999), it is unlikely to improve the plight of unskilled workers and the unemployed.

The findings discussed here suggest that for regions to gain from FDI, policies that are currently being pursued by most RDAs in the UK rely heavily on the assumption of the existence of productivity or output externalities to occur as a result of FDI. In the absence of such spillovers, demand for skilled workers, and hence wage differentials increase, and to a large extent foreign owned employment replaces domestic employment. Even in the absence of spillovers, this still represents a gain to the host region, as new technology is often introduced, and wages increase. However, this does little or nothing to alleviate structural unemployment, which is in general the rationale behind offering large subsidies to attract inward investment. Evidence is therefore emerging that FDI introduces technology into the host country, that is at least to some extent labour-augmenting. That is to say, that the imported technology leads to increased demand for skilled workers, relative to unskilled workers. This is generally interpreted to be beneficial to the host country or region, for reasons outlined by Barrel and Pain (1997). Indeed, those concerned with defining and implementing regional policy in the UK have taken this as evidence that inward investment not only generates employment, and improves the technological base of the economy, but also improves the skill-base. However, while this may to some extent be true, concern may also be expressed that inward investment is acting to increase differentials between skilled and unskilled labour.

Where technology spillovers do occur, this can be seen to provide a further benefit to the host region. If labour productivity increases, then the demand for such labour will increase, increasing both wages and employment. However, as is illustrated by Driffield and Taylor (2000), such technology spillovers again have the effect of increasing the relative 
demand for skilled workers, which again will do little to solve the problem of structural employment.

\section{Policy implications and Conclusions}

By increasing the relative demand for unskilled labour, FDI is unlikely to contribute significantly to alleviating the structural unemployment that certain regions have suffered as a result of the decline in traditional manufacturing. Indeed, there is evidence that rather than generating employment for the hitherto unemployed, many of the skilled jobs in the new foreign firms tend to be filled by people previously employed elsewhere, who are attracted by the generally higher rates of pay offered by MNEs.

Thus, while FDI certainly provides benefits to the host country or region, in terms of agglomeration economies, new technology and providing more employment for skilled workers, it is less clear that it acts to address the concerns of Morgan (1997). For example, certain regions have high levels of unemployment due to a large number of unskilled workers, with low levels of labour productivity, and low levels of training. Much of the perceived benefit of inward investment to host countries or regions, is therefore dependent on the existence of productivity spillovers occurring between the foreign and domestic sector. It is clear from previous research that FDI acts to increase wages in the domestic sector, and therefore productivity in the domestic sector has also to increase if the domestic firms are to remain competitive. There is evidence that spillovers do occur between foreign and domestic firms, but that these are by no means uniform or generic. Driffield (2000) shows that an important determinant of productivity externalities from FDI is the size of the technological advantage that the foreign firms possess, as outlined by Blomstrom et al. (1999). In addition, Driffield and Taylor (2000) show that these spillovers do lead to increased demand for skilled labour in the domestic sector, but that the extent of the spillover effect is dependent on the 
size of the foreign productivity differential. If the technology gap between the foreign and domestic sectors is very large, then it is doubtful that domestic firms can assimilate the imported technology. In such a case, wages will still be bid up, and skill differentials will increase, but without the accompanying productivity gain. In such a case therefore, while the technology gain to the host country still occurs overall, any employment gain is likely to be limited. In addition to this scenario, there is a literature developing following Neven and Siotis (1996), that shows that some FDI occurs as a result of "technology sourcing", that is that MNEs enter the host country in order to acquire local technology. Clearly, in such a case, there will still be a labour market “crowding out” effect, following Driffield (1999), but again clearly no beneficial spillover effect for the host country. It is reasonable to assume that such an investment will generate employment, probably again increasing the demand for skilled labour, but that this employment gain is likely to be limited to the direct employment creation of the investment, with some loss of employment in the domestic sector.

Despite evidence of beneficial spillover effects from FDI in terms of productivity and wages ${ }^{8}$ along with the benefits are some undesirable affects upon the labour market in that the less well skill endowed are disadvantaged. Leahy and Montagna (2000) also find that multinational activity does not always benefit the host country. It is important to have an understanding of the possible negative impacts of FDI upon the labour market as well as potential benefits for future policy analysis, however decision making to date based largely upon the latter.

\footnotetext{
${ }^{8}$ In the light of increasing wage dispersion which part of this paper has been concerned with one can argue that increasing inequality may not be such an evil (Welch, 1999). This is because increasing dispersion offers increased opportunities for individuals to specialise, such as the education response to increased educational wage premium during the last two decades (Harkness, 1996). In other words the supply response to an increase in demand for skilled labour and consequently increasing wage dispersion was for more individuals to become educated.
} 


\section{References.}

Aghion, P. and Howitt, P. (1998) Endogenous Growth Theory, Cambridge, MA: MIT Press.

Aitken, B. and Harrison, A. (1999) 'Do domestic firms benefit from direct foreign investment? Evidence from Venezuela’, American Economic Review, 89, 605-618.

Anderton, B. and Brenton, P. (1999) 'Outsourcing and low skilled workers in the UK', Bulletin of Economic Research, 51, 267-85.

Autor, D. and Katz, L. (1999) 'Changes in the wage structure and earnings inequality', in O. Ashenfelter and D. Card (eds), Handbook of Labor Economics: Volume 3A, Elsevier Science, Amsterdam, The Netherlands.

Barrell, R. and Pain, N. (1997) 'Foreign direct investment, technological change and economic growth within Europe’, Economic Journal, 107, 1770-86.

Barrell, R. and Pain, N. (1999) Innovation, Investment and the diffusion of technology in Europe: German Direct Investment and Economic Growth in Postwar Europe, Cambridge University Press.

Berman, E., Bound, J. and Griliches, Z. (1994) 'Changes in the demand for skilled labour within US manufacturing industries’ Quarterly Journal of Economics, 109, 367-98.

Berman, E. and Machin, S. (2000) 'Skill biased technology transfer: Evidence on the factor bias of technological change in developing and developed countries', Presented at the International Economic Association conference on Globalisation and Labour Markets, University of Nottingham July 2000.

Belitz, H. and Beise, M. (1999) 'Internationalisation of R\&D and multinational enterprises: The German perspective', in R. Barrell and N. Pain (eds.), Innovation, Investment and the diffusion of technology in Europe: German Direct Investment and Economic Growth in Postwar Europe, Cambridge University Press.

Blomstrom, M. (1989) Foreign Investment and Spillovers, Routledge, London.

Blomstrom, M., Globerman, S. and Kokko, A. (1999) 'The determinants of host country spillovers from foreign direct investment: Review and synthesis of the literature', NIESR, September 1999.

Blonigen, B. and Slaughter, M., 1999. 'Foreign-affiliate activity and US skill upgrading', NBER Working Paper No:7040.

Borjas, G. and Ramey, V. (1994) Time series evidence on the sources of trends in wage inequality. American Economic Review, Papers and Proceedings, 84, 10-16.

Conyon, M., Girma, S., Thompson, S. and Wright, P. (1999) 'The impact of foreign acquisition on wages and productivity in the UK', Centre for Research on Globalisation and Labour Markets, Research Paper 99/8. 
Davies, S.W. and Lyons, B.R. (1991) 'Characterising relative performance: the productivity advantage of foreign owned firms in the UK', Oxford Economic Papers, 43, 584-95.

De Mello, L.R. (1999) 'Foreign direct investment-led growth: evidence from time series and panel data’, Oxford Economic Papers, 51, 133-151.

Delbridge, R., Turnbull, P. and Wilkinson, B. (1992) 'Pushing back the frontiers: management control and work intensification under JIT/TQC regimes', New Technology, Work and Employment, 7, 97-106.

Driffield, N. (1996) Global Competition and the Labour Market, Harwood, Reading.

Driffield, N. (1999) 'Indirect employment effects of foreign direct investment into the UK', Bulletin of Economic Research, 51, 207-21.

Driffield, N. (2000) 'The impact on domestic productivity of inward investment in the UK', The Manchester School, forthcoming.

Driffield, N. and Munday, M. (2000) 'Industrial performance, agglomeration and foreign manufacturing in the UK', Journal of International Business Studies, 31, 21-37.

Driffield, N. and Taylor, K. (2000) 'Spillovers from FDI and skill structures of host-country firms’, mimeo, Cardiff Business School.

Dunning, J.H. (1979) 'Explaining patterns of international production: In defence of the eclectic theory’, Oxford Bulletin of Economics and Statistics, 41, 269-95.

Dunning, J.H. (1988a) 'The eclectic paradigm of international production: a restatement of some possible extensions’, Journal of International Business Studies, 19, 1-29.

Dunning, J.H. (1988b) Multinationals, Technology and Competitiveness. Allen and Unwin, London.

Eltis, W. (1996) 'How low productivity and weak innovativeness undermines UK industrial growth’, Economic Journal, 106, 84-195.

Eltis, W. and Fraser, D. (1992) 'The contribution of the Japanese industrial success to Britain and Europe', Nat West Bank Economic Review, 0, 2-19.

Figini, P. and Görg, H. (1999) Multinational companies and wage inequality in the host country: The case of Ireland. Weltwirtschaftliches Archiv, 134, 594-612.

Girma, S., Greenaway, D. and Wakelin, K. (1999) 'Wages, productivity and foreign ownership in UK manufacturing', Centre for Research on Globalisation and Labour Markets, Research Paper 99/14.

Gottschalk, P. and Smeeding, T. (1997) 'Cross-national comparisons of earnings and income inequality’, Journal of Economic Literature, 35, 633-87. 
Graham, E.M. (1978) 'Transatlantic investment by multinational firms: A rivalistic phenomenon ?’ Journal of Post Keynesian Economics, 1, 82-99.

Haddad, M. and Harrison, A. (1993) 'Are there positive spillovers from foreign investment? Evidence from panel data for Morocco’, Journal of Development Economics, 42, 51-74.

Harkness, S. (1996) 'The gender earnings gap: Evidence from the UK', Fiscal Studies, 17, 136.

Hill, S. and Munday, M.C. (1994) The regional distribution of foreign manufacturing investment in the UK, MacMillan, London.

Hood, N., Taggart, J. and Young, S. (1999) 'German manufacturing investment in the UK: Survey results and the economic impact.', in R. Barrell and N. Pain (eds), Innovation, Investment and the diffusion of technology in Europe: German Direct Investment and Economic Growth in Postwar Europe, Cambridge University Press.

Horstmann, I.J. and Markusen, J.R. (1996) 'Exploring new markets: Direct investment, contractual relations and the multinational enterprise', International Economic Review, 37, 119.

Hubert, F. and Pain, N. (1999) 'Inward investment and technical progress in the UK' Paper presented at the conference on "Inward investment, technological change and growth: the impact of MNCs on the UK economy." NIESR, September 1999 and RES 2000 at St Andrews.

Leahy, D. and Montagna, C. (2000) 'Unionisation and foreign direct investment: Challenging conventional wisdom?’, Economic Journal, 462, C80-C92.

Lindbeck, A. and Snower, D. (1996) 'Re-organisation of firms and labour market inequality', American Economic Review, Papers and Proceedings, 86, 315-321.

Lovering, J. (1999) 'Theory led by policy: The inadequacies of the "new regionalism" (illustrated from the case of Wales)', International Journal of Urban and Regional Research, 23, 379-95.

Machin, S. and Van Reenen, J. (1998) 'Technology and changes in skill structure: Evidence from seven OECD countries’, Quarterly Journal of Economics, 113, 1215-44.

Morgan, K. (1997) 'The learning region: Institutions, innovation and regional renewal' Regional Studies, 31, 491-503.

Morris, J., Munday, M. and Wilkinson, B. (1993) Working for the Japanese, London: Athlone.

Morris, J. and Wilkinson, B. (1995) 'The transfer of Japanese management to alien and institutional environments', Journal of Management Studies, 32, 719-30.

Motta, M (1996) Multinationals without advantages. Universitat Pompeu Fabra, mimeo. 
Neven, D. and Siotis, G. (1993) 'Foreign direct investment in the European Community: some policy issues’, Oxford Review of Economic Policy, 9, 72-93.

Neven, D. and Siotis, G. (1996) 'Technology sourcing and FDI in the EC: an empirical evaluation’, International Journal of Industrial Organization, 14, 543-60.

Nijkamp, P. and Blaas, E. (1995) 'Comparative regional policy analysis: Ex post valuation of the performance of the European Regional Development Fund.' Journal of Regional Science, 35, 579-97.

Oliver, N. and Wilkinson, B. (1993) The Japanization of British Industry: New developments in the 1990s. Blackwells, Oxford.

Peck, F.W. (1996) 'Regional development and the production of space: The role of infrastructure in the attraction of new inward investment', Environment and Planning A, 28, 327-39.

Ruane, F. and Görg, H. (1999) 'Irish FDI policy and investment from the EU', in R. Barrell and N. Pain (eds), Innovation, Investment and the diffusion of technology in Europe: German Direct Investment and Economic Growth in Postwar Europe, Cambridge University Press.

Taylor, K. (1999) 'Male earnings dispersion over the period 1973 to 1995 in four industries.' Paper presented at the annual Education Employment and Economics Group, Swansea and the annual European Association of Labour Economics, Regensburg.

Taylor, K. and Driffield, N. (2000) 'Wage dispersion and the role of multinationals: Evidence from UK panel data', Discussion papers in Economics, Cardiff Business School, No.00:022. Paper presented at the annual Education Employment and Economics Group, Southampton and the International Economic Association conference on Globalisation and Labour Markets, University of Nottingham July 2000.

Welch, F. (1999) 'In defense of inequality', American Economic Review, Papers and Proceedings, 89, 1-17.

Wren, C. and Taylor, J. (1999) 'Industrial restructuring and regional policy', Oxford Economic Papers, 51, 487-516.

Young, S., Hood, N. and Hamill, J. (1988) Foreign Multinationals and the Economy. Croom Helm, London.

Young, S., Hood, N. and Hamill, J. (1994) 'Multinational enterprises and regional economic development’, Regional Studies, 28, 657-77. 